\title{
Wpływ wybranych form rodzicielskich na zawiązywanie owoców i nasion w hybrydyzacji oddalonej trzech gatunków drzew owocowych z rodzaju Prunus (śliwa japońska, morela, ałycza)
}

\author{
Influence of selected parental forms on fruit and seed set in distant hybridization \\ of three fruit tree species of the genus Prunus (Japanese plum, apricot, myrobalan \\ plum)
}

\section{Marek Szymajda ${ }^{\oplus}$, Anita Kuras ${ }^{\oplus}$, Edward Żurawicz ${ }^{\oplus}$}

Zakład Hodowli Roślin Ogrodniczych,

Instytut Ogrodnictwa, ul. Konstytucji 3 Maja 1/3, 96-100 Skierniewice,

$\square$ e-mail: marek.szymajda@inhort.pl

\begin{abstract}
Celem badań była ocena efektywności hybrydyzacji oddalonej wybranych genotypów drzew owocowych należących do trzech gatunków z rodzaju Prunus - śliwa japońska (P. salicina Lindl.), morela (P. armeniaca L.) i ałycza (P. cerasifera Ehrh.). Program hybrydyzacji wykonano w wysokim tunelu foliowym w Sadzie Pomologicznym Instytutu Ogrodnictwa w Skierniewicach, wiosną 2019 r. Do badań użyto 8 genotypów rodzicielskich, tj. morela - 4 genotypy ('Early Orange', 'Harcot', 'Sirena', 'Somo'), śliwa japońska -3 genotypy ('Czarnuszka', 'Trumlar', D 17-73) oraz ałycza - 1 genotyp ('Amelia'). Program hybrydyzacji wykonano w układzie: śliwa japońska $\times$ morela 12 kombinacji krzyżowań, śliwa japońska $\times$ ałycza -3 kombinacje krzyżowań. Uzyskane wyniki pokazały, że wpływ genotypu śliwy japońskiej jako formy matecznej jest większy niż moreli jako formy ojcowskiej na zawiązywanie owoców w hybrydyzacji oddalonej tych gatunków. Śliwa japońska 'Czarnuszka' znacznie lepiej zawiązywała owoce niż 'Trumlar' po zapyleniu pyłkiem tych samych form ojcowskich moreli. W dojrzałych owocach znajdowały się zarówno nasiona wykształcone prawidłowo (żywotne), jak i takie, które miały pomarszczoną okrywę nasienną i w różnym stopniu zniekształcone zarodki (nieżywotne). Udział owoców z niewykształconymi nasionami był różny i zależał od krzyżowanych gatunków oraz od genotypu formy matecznej. W kombinacjach krzyżowań śliwa japońska $\times$ ałycza uzyskano więcej wykształconych nasion niż w kombinacjach śliwa japońska $\times$ morela, w stosunku do całkowitej liczby uzyskanych nasion (pestek). Obumieranie zarodków i nieprawidłowe wykształcenie otrzymanych nasion wskazuje na istnienie postzygotycznych barier krzyżowalności w krzyżowaniu śliwy japońskiej, moreli i ałyczy.
\end{abstract}

Słowa kluczowe: ałycza, krzyżowanie międzygatunkowe, morela, Prunus, śliwa japońska

The aim of the study was to evaluate the efficiency of distant hybridization of selected fruit tree varieties in three species of the genus Prunus - Japanese plum ( $P$. salicina Lindl.), apricot ( $P$. armeniaca L.) and myrobalan plum (P. cerasifera Ehrh.). The hybridization programme was carried out in a high plastic tunnel in the Pomological Orchard of the Research Institute of Horticulture in Skierniewice, in the spring of 2019. Eight parental genotypes, i.e. apricot - 4 genotypes ('Early Orange', 'Harcot', 'Sirena', 'Somo'), Japanese plum - 3 genotypes ('Czarnuszka', 'Trumlar', D 17-73) and myrobalan plum - 1 genotype ('Amelia') were used for the study. The hybridization programme was carried out while following the system of Japanese plum $\times$ apricot -12 cross combinations, Japanese plum $\times$ myrobalan plum -3 cross combinations. The obtained results showed that the influence of the Japanese plum genotype as a maternal form was greater than that of apricot as a paternal form on fruit-setting in the distant hybridization of these species. Furthermore, Japanese plum 'Czarnuszka' set fruit much better than 'Trumlar' after pollination with pollen of the same paternal forms of apricot. The ripe fruit also contained both properly developed seeds (viable), as well as those that had a wrinkled seed coat and malformed embryos (non-viable). The proportion of fruits with underdeveloped seeds varied and depended on the crossed species and on the genotype of the maternal form. In the crossing of Japanese plum $\times$ myrobalan plum, less underdeveloped seeds were obtained in relation to the total number of seeds (stones) obtained than in the crossing of Japanese plum $\times$ apricot. Embryo mortality and abnormal seed formation indicate the existence of post-zygotic barriers to crossability in the crossing of Japanese plum, apricot and myrobalan plum.

Keywords: apricot, interspecific crossing, Japanese plum, myrobalan plum, Prunus,

\section{Wstęp}

Krzyżowanie roślin należących do odległych genetycznie gatunków (hybrydyzacja oddalona) umożliwia uzyskanie nowych genotypów, charakteryzujących się innowacyjnymi cechami, jak np. zwiększona odporność/tolerancja na czynniki biotyczne i abiotyczne, mniejsza siła wzrostu roślin lub lepsza jakość owoców. Metoda 
ta znajduje zastosowanie zwłaszcza wówczas, gdy w obrębie określonego gatunku roślin brak jest źródeł genów, warunkujących pożądane cechy lub ich ekspresja jest niewystarczająca (Layne i Sherman, 1986).

Hybrydyzację oddaloną stosuje się także w hodowli roślin sadowniczych, w tym w hodowli drzew owocowych z rodzaju Prunus (Layne i Sherman, 1986, Duval i in., 1994; Hakoda i in., 1998). Jednak z krzyżowań oddalonych w obrębie rodzaju Prunus zazwyczaj otrzymuje się bardzo mało owoców w stosunku do liczby zapylonych kwiatów (Yoshida i in., 1975; Jun i Chung, 2007). Powodem niskiej efektywności hybrydyzacji oddalonej jest istnienie licznych barier o charakterze morfologicznym, anatomicznym i fizjologiczno-biochemicznym (Zenkteler, 1990). Bariery te uniemożliwiają zapłodnienie i powstanie zarodka (bariery prezygotyczne) lub zaburzają jego rozwój (bariery postzygotyczne) (Perez i More, 1985; Rubio-Cabates, Socias i Company, 1996; Liu i in., 2007).

Literatura dotycząca otrzymywania mieszańców międzygatunkowych drzew owocowych w rodzaju Prunus nie jest bogata, ale są doniesienia o mieszańcach śliwy japońskiej ( $P$. salicina Lindl.), ałyczy ( $P$. cerasifera Ehrh.) lub ich mieszańców $\mathrm{z}$ morelą ( $P$. armeniaca L.), które nazwano plumcot (Okie, 2005). W wyniku krzyżowania wstecznego (śliwa japońska $\times$ morela) $\times$ śliwa japońska otrzymano mieszańce, którym nadano nazwę pluot. Przykładem takich mieszańców są odmiany 'Flavor Fall' i 'Flavorich', otrzymane i uprawiane w ciepłym klimacie Kalifornii (Top i in., 2012).

Brak odmian moreli i śliwy japońskiej dobrze przystosowanych do uprawy w warunkach chłodniejszej strefy klimatu umiarkowanego stanowi jeden $\mathrm{z}$ najważniejszych problemów $\mathrm{w}$ uprawie tych gatunków w krajach środkowej i północnej Europy, w tym w Polsce. Drzewa tych gatunków nie posiadają dostatecznej wytrzymałości na ujemne temperatury w czasie zimy, w wyniku czego często przemarzają ich pąki kwiatowe (Szabó i Nyeki, 1994; Szabó, 2003; Yao, 2011; Szymajda i in, 2013). Hybrydyzacja oddalona może umożliwić transfer genów warunkujących wyższą wytrzymałość na mrozy zimowe np. z gatunków $P$. spinossa (tarnina) lub $P$. cerasifera do gatunków $P$. armeniaca i P. salicina (Duval i in., 1994; Layne i Sherman, 1986; Neumüller, 2011). Dobrym przykładem takich możliwości są ukraińskie odmiany 'Kometa' i 'Najdiena', które są mieszańcami śliwy japońskiej i ałyczy. Odmiany te odznaczają się większą tolerancją na mrozy zimowe niż tradycyjne odmiany śliwy japońskiej.
Celem prezentowanych badań jest ocena efektywności hybrydyzacji oddalonej wybranych genotypów drzew owocowych należących do trzech gatunków z rodzaju Prunus - śliwa japońska, morela i ałycza.

\section{Material i Metody Lokalizacja badań i material roślinny}

Badania prowadzono w 2019 r. w Zakładzie Hodowli Roślin Ogrodniczych Instytutu Ogrodnictwa w Skierniewicach. Krzyżowano 8 genotypów rodzicielskich należących do rodzaju Prunus, tj. morela - 4 genotypy ('Early Orange', 'Harcot', 'Sirena', 'Somo'), śliwa japońska - 3 genotypy ('Czarnuszka', 'Trumlar', 'D 17-73') oraz ałycza 1 genotyp ('Amelia').

\section{Program zapyleń}

Zapylenia wykonano na drzewach rosnących w wysokim tunelu foliowym w Sadzie Pomologicznym w Skierniewicach (Polska Centralna). Prowadzono je na kwiatach wykastrowanych w fazie białego, mocno nabrzmiałego zamkniętego pąka. Słabo wykształcone pąki kwiatowe usuwano. Bezpośrednio po kastracji na znamiona słupków wykastrowanych kwiatów nanoszono, przy pomocy pędzelka, pyłek o znanej żywotności. Nakładanie pyłku powtarzano w drugim dniu. Program zapyleń wykonano w następującym układzie: śliwa japońska $\times$ morela -12 kombinacji krzyżowań, śliwa japońska $\times$ ałycza -3 kombinacje krzyżowań.

Przed zapyleniami zbadano zdolność kiełkowania ziaren pyłku form ojcowskich moreli i ałyczy. W celu pozyskania pyłku wybierano pylniki z mocno nabrzmiałych pąków kwiatowych (tuż przed ich otwarciem). Pylniki suszono w temperaturze pokojowej na papierowych tackach przez kilkanaście godzin. Wysuszone ziarna pyłku wykładano na sztuczną pożywkę według Sharafi (2011), o składzie: sacharoza (15\%), $\mathrm{H}_{3} \mathrm{BO}_{3}(5 \mathrm{mg}$ $\left.\mathrm{L}^{-1}\right)$ i Bactoagar (1\%). Wzrost łagiewek oceniano po 20 godzinach inkubacji ziaren pyłku w ciemności, w temperaturze $24^{\circ} \mathrm{C}$. Za żywotne uznawano te ziarna, dla których długość wyrastającej łagiewki co najmniej dwukrotnie przekraczała średnicę ziarna pyłku (Khan i Perveen, 2008). Żywotność pyłku oceniano na minimum 100 ziarnach pyłku, pobranych losowo z większej próby, w obrębie każdego genotypu.

\section{Zawiazywanie owoców i nasion}

Uzyskane owoce liczono w fazie ich dojrzałości zbiorczej, a ich zawiązanie wyrażono w procentach w stosunku do zapylonych kwiatów. Wydobyte 
z dojrzałych owoców pestki dokładnie oczyszczono z resztek miąższu poprzez kilkakrotne ich mycie pod bieżącą wodą oraz pozbawiono endokarpów za pomocą imadła stołowego w celu wydobycia nasion. Nasiona dzielono na dwie grupy - prawidłowo wykształcone oraz zdeformowane. Do dalszych badań (ocena zdolności kiełkowania nasion) przeznaczono tylko nasiona prawidłowo wykształcone. Wykształcanie nasion wyrażono $\mathrm{w}$ procentach w stosunku do całkowitej liczby otrzymanych nasion (pestek).

\section{Stratyfikacja nasion}

Prawidłowo wykształcone nasiona odkażono w $0,5 \%$ roztworze fungicydu Kaptan zawiesinowy 50 WP (50\% kaptan) (Arysta Life Science North America Co., San Francisco, USA) poprzez moczenie przez okres 45-60 minut. Po odkażeniu nasiona wymieszano z wilgotnym podłożem do stratyfikacji (perlit), zapakowano do foliowych torebek i poddano stratyfikacji, którą prowadzono w inkubatorze do stratyfikacji nasion 'MIR-554' ('SANYO', Moriguchi, Japan) w temperaturze ok. $5^{\circ} \mathrm{C}$. Nasiona z poszczególnych kombinacji poddawano stratyfikacji w różnych terminach $\mathrm{w}$ zależności od terminu dojrzewania owoców. Pierwsze dwa przeglądy nasion wykonano po 30 i 60 dniach od rozpoczęcia stratyfikacji, a następne co $10 \mathrm{dni}$. W trakcie tych przeglądów wybierano i liczono kiełkujące nasiona. Za skiełkowane uznawano nasiona $\mathrm{z}$ widocznym 5-15 mm korzonkiem zarodkowym. Stratyfikację nasion prowadzono do 160 dnia. Zdolność kiełkowania nasion wyrażono $\mathrm{w}$ procentach $\mathrm{w}$ stosunku do liczby nasion poddanych stratyfikacji.

\section{Wyniki i Dyskusja \\ Ocena efektywności wykonanej hybrydyzacji}

W wykonanych 15 kombinacjach krzyżowań oddalonych uzyskano 1047 owoców, co stanowi 15,2\% liczby zapylonych kwiatów. W krzyżowaniu śliwa japońska $\times$ morela i śliwa japońska $\times$ ałycza zawiązanie owoców było podobne, uzyskano $15,6 \%$ oraz $12,1 \%$ owoców (Tabela 1). Ponieważ były to krzyżowania międzygatunkowe, w których występują różne bariery krzyżowalności, wynik ten można uznać za dobry. Pozytywny wpływ na zawiązanie owoców na pewno miał wybór, dokonany na podstawie badań przeprowadzonych w poprzednich latach (Szymajda i in. 2015), krzyżowań w kierunku śliwa japońska $\times$ morela oraz śliwa japońska $\times$ ałycza zamiast $\mathrm{w}$ kierunku odwrotnym oraz genotypów śliwy japońskiej zgodnych z formami ojcowskimi moreli i ałyczy. Więcej owoców w krzyżowaniu śliwa japońska $\times$ morela niż w krzyżowaniu odwrotnym uzyskali również Yoshida i in. (1975) oraz Jun i Chung (2007). Potwierdza to większą przydatność śliwy japońskiej niż moreli jako form matecznych w programach krzyżowań oddalonych tych gatunków.

Przyczyną dobrego zawiązywania owoców w krzyżowaniu śliwa japońska $\times$ morela mogła być także większa zdolność do szybszego wzrostu łagiewek pyłkowych moreli niż łagiewek śliwy japońskiej (Perez i Moore, 1985). Ponadto kwiaty śliwy japońskiej i ałyczy posiadają krótszy słupek niż kwiaty moreli w związku z czym łagiewka pyłkowa moreli, aby dotrzeć do zalążni ma do przebycia krótszą drogę niż łagiewka śliwy japońskiej w krzyżowaniu tych gatunków (Jun i Chung, 2007; Perez i Moore, 1985). Czynniki te, w mało sprzyjających warunkach pogodowych w czasie zapyleń, mogły mieć znaczący wpływ na zawiązanie owoców.

Powstawanie owoców zależało od formy matecznej śliwy japońskiej. Genotypy śliwy japońskiej 'Czarnuszka' i D 17-73, średnio dla użytych form ojcowskich moreli, dużo lepiej zawiązywały owoce niż śliwa japońska 'Trumlar'. Wyniki te sugerują, że wpływ genotypu śliwy japońskiej jako formy matecznej jest większy niż moreli jako formy ojcowskiej na zawiązywanie owoców w hybrydyzacji oddalonej tych gatunków. Ocena zdolności kiełkowania pyłku na sztucznej pożywce wykazała, że pyłek każdej formy ojcowskiej posiadał wysoką zdolność kiełkowania. Żywotność pyłku nie miała więc wpływu na różnice w zawiązywaniu owoców u form matecznych śliwy japońskiej.

Zawiązywanie owoców zależało też od krzyżowanych form rodzicielskich. Śliwa japońska 'Czarnuszka' bardzo dobrze zawiązywała owoce po zapyleniu pyłkiem moreli 'Somo,' natomiast D 17-73 po zapyleniu pyłkiem moreli 'Early Orange'. Świadczy to o różnej zgodności genetycznej krzyżowanych form rodzicielskich śliwy japońskiej i moreli oraz o ich specyficznej zdolności kombinacyjnej pod względem tej cechy. Różną zgodność genetyczną form rodzicielskich wykazano też w krzyżowaniu śliwa japońska $\times$ ałycza. Genotyp 'Trumlar' zawiązywał lepiej owoce niż genotypy 'Czarnuszka' i D 17-73 po zapyleniu pyłkiem ałyczy 'Amelia'. W badaniach Arbeola i in. (2006) zawiązywanie owoców w krzyżowaniu ałyczy i moreli także było uzależnione od krzyżowanych form rodzicielskich i wynosiło od $0,9 \%$ do $18,7 \%$. 
Tabela 1.

Table 1.

Efektywność hybrydyzacji oddalonych śliwy japońskiej, ałyczy i moreli (Skierniewice, 2019 r.)

Effectiveness of distant hybridization of Japanese plum, apricot and myrobalan plum (Skierniewice, 2019 r.)

\begin{tabular}{|c|c|c|c|c|c|c|c|}
\hline \multirow{2}{*}{$\begin{array}{c}\text { Krzyżowane formy rodzicielskie } \\
\text { Crossed parental forms } \\
+\times \widehat{\delta}\end{array}$} & \multirow{2}{*}{$\begin{array}{c}\text { Zapylone } \\
\text { kwiaty (szt.) } \\
\text { Polinated } \\
\text { flowers (No.) }\end{array}$} & \multicolumn{2}{|c|}{$\begin{array}{l}\text { Uzyskane owoce } \\
\text { Obtained fruit }\end{array}$} & \multicolumn{2}{|c|}{$\begin{array}{l}\text { Wykształcone nasiona } \\
\text { Developed seeds }\end{array}$} & \multicolumn{2}{|c|}{$\begin{array}{l}\text { Skiełkowane nasiona } \\
\text { Germinated seeds }\end{array}$} \\
\hline & & (szt.) (No.) & $(\%)^{\mathrm{z}}$ & (szt.) (No.) & $(\%)^{y}$ & (szt.) (No.) & $(\%)^{x}$ \\
\hline \multicolumn{8}{|c|}{ śliwa japońska $\times$ morela } \\
\hline Czarnuszka $\times$ Early Orange & 720 & 162 & 22,5 & 68 & 42,0 & 60 & 88,2 \\
\hline Czarnuszka $\times$ Harkot & 730 & 143 & 19,6 & 75 & 52,4 & 70 & 93,3 \\
\hline Czarnuszka $\times$ Sirena & 200 & 17 & 8,5 & 15 & 88,2 & 6 & 40,0 \\
\hline Czarnuszka $\times$ Somo & 790 & 208 & 26,3 & 173 & 83,2 & 158 & 91,3 \\
\hline $\begin{array}{l}\text { Suma } \\
\text { Total }\end{array}$ & 2440 & 530 & 21,7 & 331 & 62,5 & 294 & 88,8 \\
\hline Trumlar $\times$ Early Orange & 170 & 18 & 10,6 & 9 & 50,0 & 9 & 100,0 \\
\hline Trumlar $\times$ Harkot & 220 & 8 & 3,6 & 5 & 62,5 & 5 & 100,0 \\
\hline Trumlar $\times$ Sirena & 110 & 7 & 6,4 & 6 & 85,7 & 6 & 100,0 \\
\hline Trumlar $\times$ Somo & 85 & 6 & 7,1 & 5 & 83,3 & 5 & 100,0 \\
\hline $\begin{array}{l}\text { Suma } \\
\text { Total }\end{array}$ & 585 & 39 & 6,7 & 25 & 64,1 & 25 & 100,0 \\
\hline D $17-73 \times$ Early Orange & 570 & 158 & 27,7 & 110 & 69,6 & 108 & 98,2 \\
\hline D $17-73 \times$ Harkot & 830 & 82 & 9,9 & 63 & 76,8 & 60 & 95,2 \\
\hline D $17-73 \times$ Sirena & 750 & 23 & 3,1 & 21 & 91,3 & 21 & 100,0 \\
\hline D $17-73 \times$ Somo & 860 & 109 & 12,7 & 104 & 95,4 & 104 & 100,0 \\
\hline $\begin{array}{l}\text { Suma } \\
\text { Total }\end{array}$ & 3010 & 372 & 12,4 & 298 & 80,1 & 293 & 98,3 \\
\hline $\begin{array}{c}\text { Suma } \\
\text { Total } \\
(\text { śliwa japońska } \times \text { morela) }\end{array}$ & 6035 & 941 & 15,6 & 654 & 69,5 & 612 & 93,6 \\
\hline \multicolumn{8}{|c|}{ śliwa japońska $\times$ ałycza } \\
\hline Czarnuszka $\times$ Amelia & 150 & 10 & 6,7 & 10 & 100,0 & 6 & 60,0 \\
\hline Trumlar $\times$ Amelia & 133 & 35 & 26,3 & 34 & 97,1 & 34 & 100,0 \\
\hline D $17-73 \times$ Amelia & 590 & 61 & 10,3 & 54 & 88,5 & 52 & 96,3 \\
\hline $\begin{array}{c}\text { Suma } \\
\text { Total } \\
(\text { śliwa japońska } \times \text { ałycza })\end{array}$ & 873 & 106 & 12,1 & 98 & 92,5 & 92 & 93,9 \\
\hline $\begin{array}{c}\text { Suma (dla wszystkich kombinacji } \\
\text { krzyżowań) } \\
\text { Total (for all crosses) }\end{array}$ & 6908 & 1047 & 15,2 & 752 & 71,8 & 704 & 93,6 \\
\hline
\end{tabular}

${ }^{z}$ procent z liczby zapylonych kwiatów

${ }^{z}$ percentage of the number of pollinated flowers

y procent z liczby z calkowitej liczby uzyskanych nasion

${ }^{y}$ percentage of the total number of seeds obtained

${ }^{x}$ procent $z$ liczby $z$ liczby nasion zastratyfikowanych

${ }^{x}$ percentage of the total number of seeds subjected to stratification

W dojrzałych owocach znajdowały się zarówno nasiona wykształcone prawidłowo - żywotne, jak i takie, które miały pomarszczoną okrywę nasienną i niewykształcone zarodki - czyli uznane za nieżywotne. Z 15 kombinacji krzyżowań łącznie uzyskano 752 prawidłowo wykształcone nasiona mieszańcowe śliwy japońskiej i moreli lub ałyczy, co stanowi $71,8 \%$ całkowitej liczby otrzymanych nasion oraz tylko $10,9 \%$ liczby zapylonych kwiatów. Udział owoców z niewykształconymi nasionami był różny i zależał od krzyżowanych gatunków oraz od genotypu formy matecznej (Tabela 1). W krzyżowaniu śliwa japońska $\times$ ałycza uzyskano więcej wykształconych nasion niż w krzyżowaniu śliwa japońska $\times$ morela $\mathrm{w}$ stosunku do całkowitej liczby uzyskanych nasion (pestek). Natomiast 
spośród form matecznych genotyp śliwy japońskiej D 17-73, bez względu na użytą formę ojcowską, lepiej wykształcał nasiona niż genotypy 'Czarnuszka' i 'Trumlar'. Obumieranie zarodków i nieprawidłowe wykształcenie nasion wskazuje na istnienie postzygotycznych barier krzyżowalności, co wcześniej obserwowali w swoich badaniach także inni autorzy (Rubio-Cabates, Socias i Company, 1996; Liu i in., 2007). Pokonanie barier postzygotycznych i uratowanie przynajmniej części zarodków mieszańcowych jest możliwe poprzez zastosowanie techniki embryo-rescue (Golis i in, 2002; Kukharchyk i Kastrickaya, 2006; Liu i in., 2007). Umożliwia ona rozwój niedojrzałych zarodków i ich wzrost w warunkach in vitro, przez co staje się bardzo użytecznym narzędziem w hybrydyzacji oddalonej roślin z rodzaju Prunus (Arbeola i in., 2003).

\section{Zdolność kietkowania uzyskanych nasion mie- szańcowych}

Nasiona gatunków z rodzaju Prunus w chwili wydobycia z owoców nie są zdolne do kiełkowania, ponieważ znajdują się w fazie głębokiego spoczynku fizjologicznego (Suszka 1962, 1967). Nasiona te nie kiełkują, nawet jeżeli warunki środowiskowe, tj. temperatura, wilgotność podłoża i dostęp tlenu są odpowiednie do ich skiełkowania (Baskin i Baskin, 2004). Spoczynek ten jest przełamywany w trakcie stratyfikacji (Szymajda i Żurawicz, 2014; Szymajda i in. 2019b) pod wpływem chłodu, który powoduje rozkład związków chemicznych zwanych inhibitorami kiełkowania. Z poddanych stratyfikacji 752 nasion skiełkowało 704 czyli 93,9\%. Choć nie wszystkie nasiona wykiełkowały, to ich zdolność kiełkowania była dość dobra. Zdolność ta zależała bardziej od genotypu formy matecznej niż ojcowskiej. Niezależnie od formy ojcowskiej moreli lub ałyczy nasiona śliwy japońskiej 'Trumlar' posiadały większą zdolność kiełkowania niż nasiona śliwy japońskiej 'Czarnuszka'. Wpływ genotypu formy matecznej na zdolność kiełkowania nasion gatunków z rodzaju Prunus stwierdzono także w badaniach własnych (Szymajda i in., 2019a; 2019b) oraz innych autorów (Jensen i Kristiansen, 2009; Seliga i Żurawicz, 2011; Souza i in., 2017).

\section{Wnioski}

1. Tradycyjna hybrydyzacja oddalona śliwy japońskiej i moreli lub ałyczy odznacza się małą efektywnością, w wyniku czego uzyskuje się małą liczbę owoców i nasion mieszańcowych w stosunku do zapylonych kwiatów.

2. Genotyp śliwy japońskiej użytej jako forma mateczna ma większy wpływ niż genotyp ojcowski moreli na zawiązywanie owoców w hybrydyzacji oddalonej tych gatunków.

3. Duża część nasion uzyskanych w krzyżowaniach oddalonych śliwa japońska $\times$ morela oraz śliwa japońska $\times$ ałycza jest nieprawidłowo wykształcona (nieżywotna).

4. Nie wszystkie dobrze wykształcone nasiona mieszańcowe krzyżowanych genotypów śliwy japońskiej i moreli lub ałyczy, pomimo długotrwałej stratyfikacji, są zdolne do kiełkowania. Przy niedużej liczbie uzyskiwanych nasion jest to dużym utrudnieniem w uzyskaniu siwek mieszańcowych krzyżowanych gatunków.

5. Zdolność kiełkowania nasion uzyskanych $\mathrm{w}$ krzyżowaniu śliwa japońska $\times$ morela uzależniona jest od genotypu matecznego śliwy japońskiej.

Badania finansowano ześrodków projektu MRiRW: Badania podstawowe na rzecz postępu biologicznego w produkcji roślinnej, decyzja HOR. hn.802.4.2019 z dnia 14.05.2019 r., Zadanie nr 77.

\section{Literatura}

Arbeola, A., Daorden, M. E., García, E., Marín, J. A. (2003). Successful establishment of in vitro culture of Prunus cerasifera hybrids by embro culture of immature fruits. Acta Hort. 616: 375-378.

Arbeola, A., Daordon, M. E., García, E., Wünsch, A., Hormaza, J. I., Marín, J. A. (2006). Significant effect of accidental pollinations on progeny of setting Prunus interspecific crosses. Euphytica 147: 389-394. http:// dx.doi.org/10.1007/s10681-005-9035-x

Baskin, J. M., Baskin, C. C. (2004). A classification system for seed dormancy. Seed Science Research 14: 1-16.

Duval, H., Poëssel, J. L., Olivier, G. (1994). Evaluation and selection of progeny of an interspecific cross between Prunus cerasifera and Prunus salicina. Acta Hort. 359: 87-92.

Golis, A., Korbin, M., Pluta, S. (2002). The development of Ribes embryos by interspecific hybridisation. Acta Hort. 585: 155-158.

Hakoda, N., Toyoda, R., Tabuchi, T., Ogiwara, I., Ishikawa, S., Shimura, I. (1998). Morphological characteristies of the interspecific hybrids between Japanese apricot (Prunus nume) and Plum (P. salicina). J. Japan. Soc. Hort. Sci. 67: 708-714. http://dx.doi.org/10.2503/jjshs.67. 708

Jensen, M., Kristiansen, K. (2009). Removal of distal part of cotyledons or soaking in $\mathrm{BAB}$ overcomes embryonic dormancy in sour cherry. Propagation of Ornamental Plants Vol. 9 (3): 135-142.

Jun, J. H., Chung, K. H. (2007). Interspecific cross compatibility among plum, apricot and plumcot. Kor. J. Hort. Sci. Technol. 25 (3): 217-222. 
Khan, S. A., Perveen, A. (2008). Germination capacity of stored pollen of Ficus carica (Moraceae) and their maintenance. Pak. J. Bot. 40 (6): 2251-2254.

Kukharchyk, N., Kastrickaya, M. (2006): Embryo rescue techniques in Prunus, L. breeding. J. Fruit Ornam. Plant Res. 14 (1): 129-135.

Layne, R. E., Sherman, C. W. B. (1986): Interspecific hybridization of Prunus. HortScience. 21 (1): 48-51.

Liu, W., Chen, X., Liu, G., Liang, Q., He, T., Feng, J. (2007). Interspecific hybridization of Prunus persica with $P$. armeniaca and $P$. salicina using embryo rescue. Plant Cell Tiss. Organ Cult. 88: 289-299. http://dx.doi.org/10.1007/ s11240-007-9201-z

Neumüller, M. (2011). Fundamental and applied aspects of plum (Prunus domestica L.) breeding. W: Flachowsky, H., Hanke, V. M. (eds). Fruit, Vegetable and Cereal Science and Biotechnology. Global Science Books, s. 139-154.

Okie, W. R. (2005). 'Spring Satin' plumcot. J. Amer. Pomol. Soc. 59: 119-124.

Perez, S., Moore, J. N. (1985). Prezygotic endogenous barriers to interspecific hybridization in Prunus. J. Amer. Soc. Hort. Sci. 110 (2): 267-273.

Rubio-Cabates, M. J., Socias i Company, R. (1996). Fertilization assessment and postzygotic development in several intra- and interspecific Prunus hybrids. Euphytica 90: 325-330.

Seliga, S., Żurawicz, E. (2011). Wpływ warunków stratyfikacji na kiełkowanie nasion wiśni (Prunus cerasus L.). Zesz. Nauk. Inst.. Sad. i Kwiac. im. Sz. Pieniążka 19: 5-14.

Sharafi, Y. (2011). Pollen viability and longevity in some selected genotypes of peach, plum, prune and sour cherry. J. Med. Plants Res. 5 (2): 275-279.

Souza, A. G., Spinelli, V. M., Souza, R. O., Smiderle, O. J., Bianchi, V. B. (2017). Optimization of germination and initial quality of seedlings of Prunus persica tree rootstocks. Journal of Seed Science 39: 66-173. https://doi. org/10.1590/2317-1545v39n2171687

Suszka, B. (1962). Wpływ czynnika termicznego na ustępowanie spoczynku nasion czereśni dzikiej. Arboretum Kórnickie 7: 189-275.

Suszka, B. (1967). Studia nad spoczynkiem i kiełkowaniem nasion różnych gatunków z rodzaju Prunus, L. Arboretum
Kórnickie 12: 221-282.

Szabó, Z., Nyeki, J. (1994). Frost jnjury to European and Japanese plum flower buds in Hungary. Kerteszeti Tudomany 26 (1): 1-15.

Szabó, Z. (2003). Frost injuries of the reproductive organs in fruit species. W: Kozma, P., Nyéki, J., Soltész, M., Szabó, Z. Floral biology, pollination and fertilisation in temperate zone fruit species and grape. Akadémiai Kiadó, Budapest, p. 59-74.

Szymajda, M., Pruski, K., Żurawicz, E., Sitarek, M. (2013). Freezing injuries to flower buds and their influence on yield of apricot (Prunus armeniaca L.) and peach (Prunus persica L.). Can. J. Plant Sci. 93: 191-198. http://dx.doi. org/10.4141/cjps2012-238

Szymajda, M., Żurawicz, E. (2014). Seed genotypes for harvesting seeds in the production of generative rootstocks for peach cultivars. Horticultural Science 41 (4): 160-166.

Szymajda, M., Sitarek, M., Pruski, K., Żurawicz, E. (2019)a. A potential of new peach (Prunus persica L.) seed tree genotypes for the production of generative rootstocks. Sci. Hortic. 256. https://doi.org/10.1016/j.scienta.2019. 108618.

Szymajda, M., Żurawicz, E., Maciorowski, R., Pruski, K. (2019) b. Stratification period combined with mechanical treatments increase Prunus persica and Prunus armeniaca seed germination. Dendrobiology 81: 47-57.

Szymajda, M., Napiórkowska, B., Korbin, M., Żurawicz, E. (2015). Studies on the interspecific crossing compatibility among three Prunus species and their hybrids. Horticultural Science 42 (2): 70-82. https://doi.org/10.17221/273/ 2014-HORTSCI

Top, B.L., Russell, D.M., Neumüller, M., Dalbó, M.A., Liu, W. (2012). Plum. W: Badenes, M. L., Byrne, D. H. Fruit Breeding: Handbook of Plant Breeding 8. Springer Science+Business Media, LLC, p. 576-621. http://dx.doi. org/10.1007/978-1-4419-0763-9

Yoshida, M., Kyotani, H., Yasuno, M. (1975). Studies on interspecific crossing in Prunus spp. I. Cross compatibility. Jpn. J. Breeding. 25 (1): 17-23.

Yao, S. (2011). Winter 2011 low-temperature injury to stone fruit buds in New Mexico. HortTechnology 21 (6): 767-772

Zenkteler, M. (1990). In vitro fertilization and wide hybridization in higher plants. Plant Sci. 9: 267-279. http://dx.doi. org/10.1080/07352689009382290 